\title{
GLOBALIZATION AND TEACHER DEVELOPMENT FOR SPOKEN ENGLISH INSTRUCTION ${ }^{1}$
}

\author{
Christine C. M. Goh \\ National Institute of Education, Nanyang Technological University, Singapore \\ email: christine.goh@nie.edu.sg
}

\begin{abstract}
The impact of globalization is experienced most strongly in business and commerce but also increasingly in education. As a result, some scholars have called for a re-envisioning of the role of teachers to model what it means to be a global citizen. In this paper, I acknowledge the need for ESL/EFL teachers to re-examine their identity and roles in light of these global developments. At the same time, I argue that teachers should not lose sight of the importance of honing the craft of teaching English so as to increase their professional capital to mediate the impact of globalization for their students. This article first discusses the changing roles of teachers in a globalized world and highlights the implications for English language teaching and learning. The ideas are further related to teaching second language oracy (speaking and listening) because of its centrality in developing important 21 st Century skills in the globalized world. The article also offers ways in which teacher education that takes cognizance of globalization forces can develop ESL/ EFL teachers' knowledge and beliefs to play their new roles more effectively.
\end{abstract}

Keywords: globalization, global citizen, global development, peofessional capital

\section{GLOBALISASI DAN PENGEMBANGAN GURU UNTUK PEMBELAJARAN BERBICARA BAHASA INGGRIS}

\begin{abstract}
Abstrak: Dampak globalisasi yang paling kuat dialami sektor bisnis dan perdagangan, tetapi juga semakin meningkat dalam pendidikan. Oleh karena itu, beberapa sarjana telah menuntut visi baru dari peran guru untuk menjadi suri tauladan bagaimana menjadi bagian dari warga negara global. Dalam tulisan ini, saya mengakui perlunya guru bahasa Inggris sebagai bahasa kedua atau sebagai bahasa asing (ESL/EFL) untuk memeriksa kembali identitas dan peran mereka dalam perkembangan global. Pada saat yang sama, saya berpendapat bahwa guru tidak boleh melupakan pentingnya mengasah keterampilan mengajar bahasa Inggris sehingga dapat meningkatkan modal profesional mereka untuk memediasi dampak globalisasi bagi siswanya. Bagian awal artikel ini membahas perubahan peran guru dalam dunia global dan menyoroti implikasi pengajaran dan pembelajaran bahasa Inggris. Kemudian, ide-ide yang terkait mengajar keterampilan berbicara dan menyimak (oracy) dalam bahasa kedua karena pentingnya dua keterampilan berbahasa itu dalam mengembangkan keterampilan penting abad ke-21 dalam dunia global. Artikel ini juga menawarkan cara-cara di mana pendidikan guru yang menyadari adanya kekuatan global dapat mengembangkan pengetahuan dan keyakinan guru-guru ESL/EFL untuk memainkan peran baru mereka yang lebih efektif.
\end{abstract}

\footnotetext{
${ }^{1}$ A version of this paper was delivered at the $5^{\text {th }}$ CONAPLIN in Bandung, Indonesia, $24^{\text {th }}-25^{\text {th }}$ September 2012.
} 
Kata kunci: globalisasi, warga global, pembangunan global, modal profesional

Globalization refers to the process of interaction, interconnection and integration of people, businesses and cultures across national boundaries, supported by new technologies that enable speed in communication and exchanges. It is "characterized by the extensive flow of information, ideas, images, capital and people across increasingly permeable political border due to economic and technological change" (Harper \& Dunkerly, 2009, p.56) Although these features of connectedness beyond political boundaries have been present in the past centuries ago, the scope, volume and speed of such exchanges are unprecedented. The impact of globalization can be felt in many countries in local lives and on the national stage while very few countries are exempted from this experience. One of the areas in which this impact is experienced most keenly is in business and commerce, but the forces of globalization are also increasingly experienced in education. This has given rise to many academic discussions about education and teaching in a globalized world, with some scholars, such as Luke (2004) calling for the role of teachers to be re-envisioned as "transcultural and cosmopolitan", as they are increasingly expected to model what it means to be a global citizen (p. 1438).

How should teachers and teacher educators in the field of English language teaching respond to such a call? In this paper, I argue that while it is important to acknowledge the broad social implications of globalization for teacher education, teacher educators should continue to help teachers-to-be and practising teachers hone the craft of teaching English and develop greater professional capital by being a versatile practitioner with a strong knowledge and skills base. These competencies that they develop will undergird teachers' changing beliefs about their roles as mediators of learning in the globalized world and enable teachers to adapt to new educational landscapes from an informed professional position. This article first discusses the changing role of teachers in a globalized world and highlights the implications for ESL/EFL teaching and learning. These ideas are further discussed in the teaching speaking and listening, offering suggestions on how teachers can teach these two language skills effectively to address their students' needs for the $21^{\text {st }}$ Century.

\section{ENGLISH LANGUAGETEACHERS IN A GLOBALIZED WORLD}

Luke (2004) argues that teachers for our globalized world need to be ready to engage with the global while rooted in the local; hence, the currency of the term "glocal" which has been used by many authors. 'Glocal' teachers are teachers who are willing to interact and collaborate with teachers, researchers and other educationalists across national boundaries. Teachers for a globalized world are ones who are ready to accept and embrace diversity within and beyond their own culture and educational and professional space. Luke's re-envisioned role of teachers for a globalized world that is driven by new needs and technologies have important implications for teacher development programmes. Such a view of teachers is an interesting and appealing one, and speaks directly to the type of globallyready learners that many education institutions aim to nurture. More importantly, it speaks to the pressing need for teachers to reassess their roles and contributions to the education of the young people in their countries in a time of great economic and cultural changes, and to reclaim the prestige and symbolic capital that teaching as a profession holds. 
While this view of a re-envisioned teacher for the globalized world is important to the shaping of teacher identity, it does not illuminate the importance of other aspects of teachers' work with reference to the subjects that they have to teach. In fact, such a broad and generic view of the teacher's role runs the danger of ignoring the craft of teaching for specific subject areas, such as EFL/ESL. A broad sociocultural view of teachers' role offers insights for teacher development in the way teachers should view themselves and how other people should be encouraged to view the profession. It does not, however, address what is happening in the language classroom and veils rather than illuminate the way teachers can build up the symbolic and professional capital that is needed for them to conduct their work effectively. This is not a criticism of Luke's view as he is concerned with more macro issues about teacher roles and identity in general in the age of globalization and does speak directly to the teaching of any curriculum subject to begin with. He is mainly cautioning against a narrow and parochial view of teacher preparation that has been the course of the day in many teacher education programmes all over the world, as well as pointing to the problem with some new practices afforded by globalization. Nevertheless, a socialized view of teacher learning remains an attractive one, but it can only be beneficial to teachers and teachers-inpreparation when it is incorporated into models of language teacher education where domain-specific competencies are developed. Importantly, ESL/ EFL teacher development should not lose sight of the role of teachers in facilitating learners' mental and emotional processes needed for successful language learning. Teachers will also need to be cognizant of the implications of globalization for teaching English which is increasingly viewed as an international language (McKay, 2002).
According to a Warschauer(2000, p. 511), globalization has implications for English language teaching and learning in the three ways. Firstly, we will see further spread of English as an international language and a shifting of authority to nonnative speakers and dialect. Secondly, economic and employment trends is changing the way English is used, particularly in presentation, discussion and interpretation of ideas. Thirdly, old notions of literacies limited to reading and writing from traditional print sources are being transformed by new information technologies to include a broad range of multiple literacy skills.

Globalization has indeed resulted in an unprecedented number of people speaking and learning English. Traditionally, English is used when people from a nonEnglish speaking country have to communicate with people from an Anglophone country, such as the US, UK and Australia/ New Zealand. Increasingly, however, communication in English takes place predominantly among speakers from nonAnglophone countries who needed to speak in a language that both parties can understand. In many countries there is also the phenomenon of children growing up speaking English rather than or in addition to a language of their parents' ethnicity. The exponential spread of English and the ways it is acquired and used as a result of globalization has given rise to a variety of new nativized or localized Englishes, including Asian Englishes (Rubdy, Zhang \& Alsagoff, 2011). Because of the transnational movements of people, the learning of English now increasingly occurs in a linguistically diverse context in the same country. In the past, English classes in a non-Anglophone country traditionally consisted of students who spoke the same language or at least share broad linguistic backgrounds. In countries such as Japan, it is not unusual to find nonJapanese students sitting alongside Japanese students in an English language class 
because the latter have come from other non-English speaking countries to work and live in Japan (Kubota \& McKay, 2009).

Economic changes and shifts in seats of economic power have further influenced the way intercultural communication is perceived and learned. Kumaravadivelu 2008) argues that instead of an ethnocentric deductive approach where western cultural behaviours are treated as the norm against which others are measured, intercultural communication should be viewed as a complex process that requires the development of both linguistic and pragmatic skills and understanding across all cultural groups. The question of which standards to be promoted in language classrooms will naturally arise (McKay, 2002). Technological innovations in the way information is communicated means that learners have to develop new skills in searching, using and producing online information in English. In addition the proliferation of synchronous and asynchronous on-line communication will require skills that transcend basic reading and writing skills to include abilities to demonstrate cognitive and social features of oral communication.

In our discussion of globalization it would be impossible not to consider the skills that individuals need to succeed in the $21^{\text {st }}$ Century. Partnership for $21^{\text {st }}$ Century Skills (2011) identified these to be learning and innovation skills, information, media and technology skills, and life and career skills. Of these skill sets, learning and innovation skills are most relevant to our discussion about teaching spoken English to language learners. The component skills of creativity, critical thinking, communication and collaboration rarely develop individually or in a vacuum, but frequently through speaking with and listening to others. The process of interacting with peers and more knowledgeable others through the process of talk can help individuals express, synthesize, evaluate and apply ideas that are jointly constructed.

What do these global changes in the way individuals learn, make meaning and produce knowledge mean for English language teachers? How should teacher educators view these developments and draw support in preparing teachers for the challenging task of developing language learners' English competencies of speaking and listening? As I have argued earlier, while it is important to envision an enhanced role for English language teachers in the globalized world, it is just as important if not more to ensure that teachers acquire competencies for teaching English language knowledge and communication skills. In other words, teachers and teacher educators would need more than acknowledging a socialised view of a teacher's role and function in our globalized world. They need theoretical perspectives and pedagogical principles that can speak to the practical and day-today endeavours of teaching and understanding how students learn in this new context. To illustrate this point, examples from teaching speaking and listening are discussed next.

\section{TEACHING ENGLISH COMPETENCIES OF SPEAKING AND LISTENING}

Teachers' attention to speaking and listening skills must begin with an understanding of the concept of oracy. A term coined by British professor of education, Andrew Wilkinson in 1965, oracy refers to an individual's general ability in using the oral skills of speaking and listening. It aimed to capture the essence and the importance of oral skills in the way the terms 'literacy' and 'numeracy' represented abilities to read and write and to think scientifically or quantitatively. Wilkinson noted that the absence of a term to represent mastery of oral skills was indicative of the neglect in developing speaking and listening skills. This neglect 
was not only felt in the first language context that Wilkinson was working from but it was also true in the teaching of second and foreign languages at the same time. The importance of oracy is further emphasised by Barnes (1988) who argued that the function of oracy is to serve as a tool by which students can "engage through speech with important aspects of the social and physical world [...] Using language in the world is not just a matter of skills but of understanding that world in all its complexity and variety, and knowing how to influence it" (p.48, 52). This observation is even more relevant today for English language learners in the globalized world where English has become a default language for transnational and intranational communication.

Good oracy abilities are important for all face-to face communication, and with the advances in technologies, oracy is the channel by which much communication occurs between people separated by physical space through facilities such as Skype and other types of on-line talk. Since speaking and listening often occur together in face-to-face interactions, the two skills are often practiced in an integrated manner in many oral communication lessons. In research and theoretical discussions, however, they are often treated individually, as each is a different construct and needs to be understood differently. Accordingly, in this article, speaking and listening are discussed separately to highlight the developments in approaches to teaching these two skills.

\section{TEACHING SPEAKING}

Approaches to speaking instruction have seen many changes over the past few decades. Burns (1998) categorised these approaches into two main types. The first is the direct/controlled approach. It focuses directly on developing isolated speaking skills and is concerned with accuracy of sentence structures and other language forms, chiefly being pronunciation. It emphasizes practice of language forms to produce increasingly accurate production while at the same time aims to raise learners' awareness about grammar and discourse structures. Common practice activities in the past include drills for language pattern practice and structure manipulation. Another type of controlled learning activity involves language analysis tasks where learners' attention is drawn to specific language features as a way of increasing their language awareness. Direct/controlled speaking lessons tend to be led by the teacher who provides the model for speech practice and leads in consciousness-raising activities.

The second approach is called the indirect/transfer approach. It focuses on the production of speech during communicative activities, such as pair work, and is more concerned with speech fluency. It involves learners in practising spoken language for special functions and purposes. For example, they may be asked to describe a picture to a partner who has not seen the picture, or role play a situation where a customer complains about poor service or damaged goods. The basic assumption of the indirect approach is that when learners practise how to speak effectively in class, they will transfer the speaking skills developed through such communicative activities to real-life situations. Learning activities have a high degree of authenticity (similarity to real life communication) in the topics that learners work on and the skills that they practice. These activities are typically learnercentred, where learners do most of the talking and the teacher takes on the role of facilitating understanding of task requirements and use of language. Unlike the direct approach, there is no explicit focus on language in transfer activities for speaking practice.

Both direct and in-direct approaches help learners to practise speaking skills in a variety of ways to improve accuracy and fluency, but neither of them effectively 
supports key processes of second language speaking development. For example, the trade-off for accuracy practice is the lack of authenticity in communication through face-to-face communication, particularly in situations where negotiation for meaning is necessary. Thus learners practise pronunciation and grammar using mainly isolated sentences without consideration for the context in which oral communication takes place. The current discussion of globalization would also raise the questions of whether pronunciation accuracy has not been over-emphasized and what should be accepted as standard in learners' pronunciation. The indirect approach, on the other hand, places so much emphasis on fluency practice that attention to grammatical accuracy and discourse structures is often neglected, as Bygate(2001) has pointed out.

To address this mainly dichotomous approach to speaking development, a holistic approach which uses the Teaching Speaking Cycle as a model for planning tasks and activities for speaking classes has been proposed (Goh \& Burns, 2012). The Cycle guides teachers in their instruction through seven phases:

1. Focus learners' attention on speaking.

2. Provide input and/or guide planning.

3. Conduct speaking tasks.

4. Focus on language/discourse/skills/ strategies.

5. Repeat speaking tasks.

6. Direct learners' reflection on learning.

7. Facilitate feedback on learning.

The different stages provide opportunities for learners to focus their attention on accuracy as well as practise their use of language in both planned and spontaneous speech. More importantly, it increases the learners' metacognitive awareness by helping them reflect on their own experiences as speakers of another language and providing them with feedback on their learning. These experiences are often absent from speaking activities where students are often asked to complete tasks all by themselves with minimal input and feedback from teachers and peers, and where the value of individual reflection on learning is also often overlooked.

\section{TEACHING LISTENING}

Over the past five decades, listening instruction has gradually shifted its focus from a heavily text-based approach to a greater concern for the communication and learning needs of learners, reflecting a deepening understanding of the construct of learner listening as a cognitive, social and communication skill. In the 1950's and 6o's, text comprehension-based techniques were the order of the day as listening instruction was influenced by practices in the teaching of other language communication skills, particularly reading. Learners were asked to listen to written passages read aloud and they had to demonstrate their understanding of listening passages by giving the correct answers. These texts often contained very few grammar features of spoken texts; they contained long sentences with many embedded ideas and were not easy to process in real time when listening. The activities were in fact a disguised form of reading comprehension done through the spoken medium. Although techniques involving written texts have largely given way to others that are more communication-oriented. Such comprehension-based techniques have persisted even till today in some listening classes.

We have indeed seen changes in the types of spoken texts used for listening practice. In the 1970's and 80's, when Communicative Language Teaching methodology gained popularity in many places such as Europe and Asia, texts used in listening classes consisted of spoken texts that attempted to simulate a high degree of authenticity or that were recorded from non-teaching materials such as movie dialogues, songs and radio programmes. Recorded texts that were scripted for 
language teaching included many features of spontaneous speech found in real life interaction, such as repetitions, hesitations and shorter or incomplete utterances. Learners were also asked to do tasks that had greater authenticity, for example, listen to a talk and take notes. In the 1990's to the present, listening instruction has been heavily influenced by a socio-cognitive paradigm that addresses learner needs such as cognitive processing demands and anxiety. The strategy approach within this paradigm aimed to train learners to use a range of strategies to handle the demands of listening (Mendelsohn 1998).

Recently, the strategy approach was enhanced in the form of the metacognitive approach which engages learners in a range of listening activities that focus on learning and language (Vandergrift \& Goh, 2012). Metacognitive activities are integrated into listening lessons to help learners deepen their understanding of themselves as L2 listeners and the demands and process of L2 listening. The cognitive and social processes of listening were acknowledged, and learners have opportunities to explore and practise these processes in their own listening. In addition, the activities also provide opportunities for learners to practise and acquire strategies on how to manage their comprehension and learning through planning, monitoring and evaluating. Two complementary methods were proposed for implementing the approach:

a) A pedagogical sequence for listening to pre-recorded texts which consists of five stages which take learners through the process of listening:

- Pre-listening-planning/predicting stage

- First verification stage

- Second verification stage

- Final verification stage

- Reflection and goal setting

b) Task-based lessons for one-way and interactional listening that make use of three stages of pre-listening, whilelistening and post-listening. The meta- cognitive approach expands the scope and purposes of the pre- and postlistening phases to include activities that develop learners' have orientations towards language and metacognitive awareness.

\section{TEACHER COGNITION AND THE TEACHING OF SPEAKING \& LISTENING}

The above discussion of teaching approaches to second language oracy alluded to changes in the way the constructs of speaking and listening have been conceptualized respectively for language development. These changes have mainly been informed by theories of speech processing and language comprehension, second language acquisition, language performance and language use, learning and motivation, and last but not least, metacognition. How should teachers and teacher educators evaluate and apply these ideas in light of the impact that globalization has on English language teaching and the role of teachers?

Before an attempt is made to answer this question, it is necessary to consider the way teacher thinking can influence the decisions teachers make about their teaching. The knowledge, beliefs and thoughts that teachers possess are collectively known as teacher cognition, "the unobservable cognitive dimension of teaching" which heavily influences the observable actions of teachers' practice (Borg, 2003, p.81). The way teachers think about theory and principles pertaining to oracy development will directly influence the way they plan and deliver their lessons for speaking and listening. As beginning teachers develop to become active and reflective professionals, they have to not only master the routines of teaching but also make moment to moment decisions that influence these routines. Like experienced teachers, they also have to make on-the-spot decisions in class which may cause them to modify or abandon 
what they have planned to do when preparing for a lesson. At the same time, they are also cultivating beliefs or views about themselves, their teaching and their learners through their lived experiences in day-to-day teaching.

Although English teachers have become the focus of much teacher cognition research in recent years, relatively little has been documented about teacher cognition concerning the teaching of spoken English skills. In a study in Singapore, it was found that English Language teachers felt they were less knowledgeable in teaching listening and speaking compared with teaching other areas of English such as reading, writing, grammar and vocabulary (Goh, Zhang, Ng $\&$ Koh, 2005). While the teachers believed that oracy development was important for their students, those teaching secondary schools also admitted to spending the least amount of class time on these two skills because the skills carried less weighting in high stakes examinations. In a survey study in the USA that investigated elementary school teachers' self-reported knowledge about oral English instruction, DeBoer (2007) found that one third of her 275 respondents reported less than adequate knowledge for teaching oral skills.

Research has also been conducted among East Asian teachers' to understand their perceptions about their own spoken English proficiency and their confidence in teaching English. Butler (2004) found that the majority of the 500 plus elementary school teachers surveyed in Korea, Japan and Taiwan felt that they did not have the necessary proficiency to teach English at the elementary school level. In a more recent study in China, Chen and Goh (forthcoming) found that the majority of 527 teacher respondents reported inadequate knowledge about how to teach oral skills, and that the teachers' knowledge about teaching spoken English and their students' needs were significantly influenced by their own learning experiences, self-perceived speaking ability and familiarity with teaching methodologies.

Research in teacher cognition has shown the important influence that it has on teaching and learning a second language. None of the studies so far, however, has directly taken into consideration the impact of globalization on teachers' thinking. It would also be helpful for teachers themselves to re-examine their beliefs and knowledge about teaching speaking and listening in light of the effects globalization might have on their decision-making processes and classroom practice.

\section{IMPLICATIONS FOR TEACHER EDUCATION}

At the start of this paper, I discussed Luke's (2004) view concerning the changing roles of teachers in the face of the economic and sociocultural changes resulting from globalization. I also put forward the view that although the reenvisioning of teachers' role as one of a transnational and cosmopolitan professional working and learning beyond national boundaries is an appealing one, it does not speak directly to the day-to-day needs of teaching a language in the classroom. Language teachers would still need to have knowledge and skills for helping their students acquire the language. While pre-service teachers have to develop rudimentary understanding and skills for their work, in-service teachers need to hone their craft of teaching through improving their knowledge about teaching English that they gather from reflecting on experiences and professional development courses.

I would like to suggest that teachers consider the existing literature on teaching speaking and listening and study the implications of globalization for the planning of lessons and instructional materials. Teachers who are familiar with current discussions on theory and principles will be in a good position to evaluate and apply or adapt these ideas for their 
respective contexts. Existing methodology courses can further provide new and additional areas of focus such as the following:

- The importance of oracy development for English language learners' participation in the $21^{\text {st }}$ Century

- Skills for teaching, managing and modeling speaking and listening processes in the language classroom

- Teachers' identity and awareness of the world in their chosen profession of teaching ESL/EFL

Teacher educators can also re-envision the role of English teachers in their respective countries so that the teachers not only develop personally but also help their students develop in ways that are relevant to the $21^{\text {st }}$ century. Here are some questions that could guide this re-envisioning, particularly in relation to developing teacher competencies for teaching speaking and listening:

- How can teachers from their respective local backgrounds develop a global outlook?

- How can teacher preparation and professional development courses help teachers themselves acquire $21^{\text {st }}$ century skills for learning and innovation (creativity, critical thinking, communication and collaboration)?

- What dispositions and skills would help teachers in their task of preparing their students for the use of English in the globalized world?

- What should the goals be for preparing teachers to acquire and teach the standards accepted for spoken English?

- How can teacher education programmes include new technologies and forms of new literacies to enhance oracy development?

\section{CONCLUSION}

With so much talk about the rapid globalization of our world, there is a tendency for us to focus our attention only another macro social context of teaching and learning. Sensible as this might seem, it does not directly address the professional needs of many EFL/ESL teachers and the learning needs of their students. In addition to embracing a socialised view of spoken English, teachers need to continually reexamine their own theories about how learners develop spoken English competencies, as well as increasing their own understanding from the available literature. In relation to teaching spoken English competencies that we are concerned with in this article, it is important that adequate time is spent on improving their knowledge about the constructs of second language speaking and listening, the nature and demands of speaking and listening tasks for students, and methods and principles for planning and delivering speaking and listening lessons. Teachers-to-be and practising teachers also need to examine their own attitude and beliefs concerning new and emerging varieties of English and how they would like to respond to these developments in their own speaking and listening classes. They should also explore their own understanding of notions of communication resulting from new technologies and transnational interactions. A teacher of spoken English for our globalized world will therefore need to develop heightened awareness of their cosmopolitan role and acquire a sound understanding of principles for teaching in a new social, economic and linguistic landscape.

\section{REFERENCES}

Barnes, D. (1988). The politics of oracy. In M. Maclure, T. Phillips, \& A. Wilkinson, Oracy matters: The development of talking and listening in education. Philadelphia, PA, USA: Open University Press.

Borg, S. (2003b). Teacher cognition in language teaching: A review of research on what language teachers 
think, know, believe, and do. Language Teaching, 36(2), pp. 81-109.

Burns, A. (1998). Teaching speaking. Annual Review of Applied Linguistics, 18, pp. 102-123.

Butler, Y. G. (2004). What level of English proficiency do elementary school teachers need to attain to teach EFL? Case studies from Korea, Taiwan, and Japan. TESOL Quarterly, 38(2), pp. 245-278.

Bygate, M. (2001). Effects of task repetition on the structure and control of oral language. In M. Bygate, P. Skehan \& M. Swain (Eds.), Researching pedagogic tasks: Second language learning, teaching, and testing (pp. 23-48). Harrow: Pearson Education.

Chen, Z. \& Goh, C. C. M. (Forthcoming) Teacher knowledge about oral english instruction and teacher profiles: An EFL perspective. Teacher Development.

DeBoer, B. B. (2007). Effective oral language instruction: A survey of Utah $K-2$ teacher self-reported knowledge. Unpublished doctoral dissertation, Utah State University, Utah, United States. Retrieved from http://proquest.umi.com/pqdweb?did= $1417812351 \& \mathrm{Fmt}=7 \&$ clientId $=15653$ $\&$ RQT $=309 \&$ VName $=$ PQD

Goh, C. C. M \& Burns, A. (2012). Teaching speaking: A holistic approach. New York: Cambridge University Press

Goh, C., Zhang, L. J., Ng, C. H., \& Koh, G. H. (2005). Knowledge, beliefs and syllabus implementation: A study of English language teachers in Singapore. Singapore: Graduate Programmes \& Research Office, National Institute of Education, Nanyang Technological University. Harper, H. \& Dunkerly, J. (2009). Educating the world: Teachers and their work as defined by the United Nations Educational, Scientific and
Cultural Organization. Current issues in comparative education, Teachers College, Columbia University, 12(1), pp. $56-65$

Kubota, R., \& McKay, S. (2009).

Globalization and language learning in rural Japan: the role of English in local linguistic ecology. TESOL Quarterly, 43(4), pp. 593-619.

Kumaravadivelu, B. (2008). Cultural globalization and language education. New Haven, CT.: Yale University Press.

Luke, A. (2004) Teaching after the market: from commodity to cosmopolitan. teachers college record, 106(7), pp. 1422-1443

McKay, S. L ( 2002) Teaching English as an international language. Oxford: Oxford University Press.

Mendelsohn, D. (1998). Teaching Listening. Annual Review of Applied Linguistics 18, pp. 81-101.

Partnership for $21^{\text {st }}$ Century Skills (2011). Framework for $21^{\text {st }}$ century learning. Retrieved from: http://www.p21.org/storage/documents /P21_Framework.pdf

Rubdy, R., Zhang, L. J., \& Alsagoff, L. (2011). The dynamics of Englishes in Asia: Description, innovation and application in a globalised world. In L. J. Zhang, R. Rubdy, \& L. Alsagoff (Eds.), Asian Englishes: Changing perspectives in a globalised world (pp. 1-25). Singapore/London/New York: Pearson Prentice Hall.

Vandergrift, L. \& Goh, C. (2012). Teaching and learning second language listening: Metacognition in action. New York: Routledge

Warschauer, M. (2000). The changing global economy and the future of English teaching. TESOL Quarterly, 34(3), pp. 511-35.

Wilkinson, A. (1965). Spoken English. Education review occasional publications number two. Birmingham: University of Birmingham. 